\title{
A Case Report of a Ganglion Cell Containing Giant Pituitary Adenoma Showing Unusual Demographic and Radiological Features
}

\author{
Anil Felix Angelo Fonseca ${ }^{1}$ Kishore T. Vijaya ${ }^{1}$ \\ ${ }^{1}$ Department of Laboratory Medicine, Care Hospital, Hyderabad, \\ India \\ 2 Department of Neurosurgery, Care Hospital, Hyderabad, India \\ ${ }^{3}$ Department of Neuroradiology, Care Hospital, Hyderabad, India \\ Indian J Neurosurg 2017;6:203-205.
}

B. S. Siva Reddy ${ }^{2}$ Ravi Verma ${ }^{3}$

Address for correspondence Anil Felix Angelo Fonseca, DCP, MD,
Department of Lab Medicine, Care Hospital, Hyderabad, 500001,
India (e-mail: dranilfonseca@rediffmail.com).

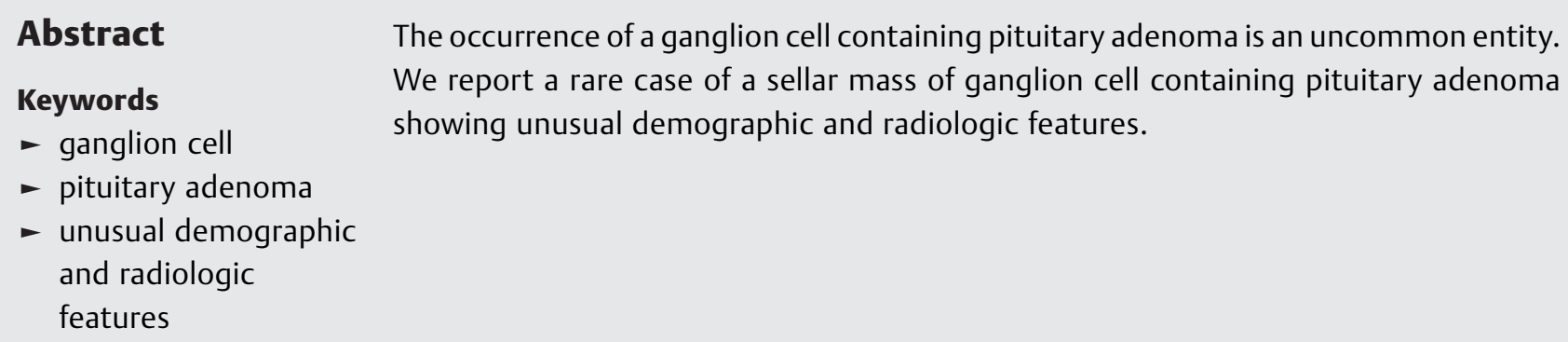

\section{Introduction}

A preoperative diagnosis of a ganglion cell component in a pituitary adenoma is very difficult, because most of these cases present clinically and radiologically as pituitary adenomas. The definitive diagnosis is determined by histopathologic study.

The aim of the article is to report a ganglion cell component in a pituitary adenoma seen as single-scattered cells amidst the larger component of pituitary adenoma. The awareness of this entity prompts a pathologist to proceed with immunohistochemical (IHC) marker studies and confirm the presence of ganglion cells in a pituitary adenoma.

\section{Case Report}

A 25-year-old man was admitted to our hospital with a 2-year history of headache and 6-month history of memory disturbances and behavioral changes. Physical examination, hematologic, and biochemical parameters were within normal limits.

Magnetic resonance imaging (MRI) revealed a sellar lesion eroding the right sphenoidal sinus and extending up to the medial temporal gyrus and pons ( - Fig. 1) with engulfment of internal carotid, basilar, middle, and anterior carotid artery.

The patient underwent partial excision of the pituitary tumor by transsphenoidal endoscopic endonasal approach. The postoperative period was uneventful.

Histologically, the tumor was composed of sheets and nodules of medium to large polygonal cells with pleomorphic round to oval vesicular nuclei, one or more prominent nucleoli, and moderate to abundant acidophilic granular cytoplasm. Few cells showed bizarre nuclei (pituitary adenoma component) intermingled with the few scattered multinucleated cells having dark staining nuclei and dense cytoplasm (ganglion cell component) (-Fig. 2). Mitosis was rare, and no necrosis or endovascular proliferation was noted. On IHC, synaptophysin was positive in both components (-Fig. 3) and neurofilament protein (NFP) was positive in cytoplasm of larger multinucleated ganglion cells (-Fig. 4). Glial fibrillary acidic protein (GFAP) () was negative in both types of tumor cells. $K_{i} 67$ index was $2 \%$. IHC for pituitary hormones including growth hormone $(\mathrm{GH})$, adrenocorticotropic hormone (ACTH), prolactin, and follicle-stimulating hormone (FSH) showed positivity for prolactin ( - Fig. 5 ) in the adenoma component. received

April 8, 2015

accepted after revision

January 18, 2016

published online

October 10, 2017
DOI https://doi.org/

10.1055/s-0037-1606862. ISSN 2277-954X. (c) 2017 Neurological Surgeons' Society
of India

License terms

(c) $(1) \$$ 


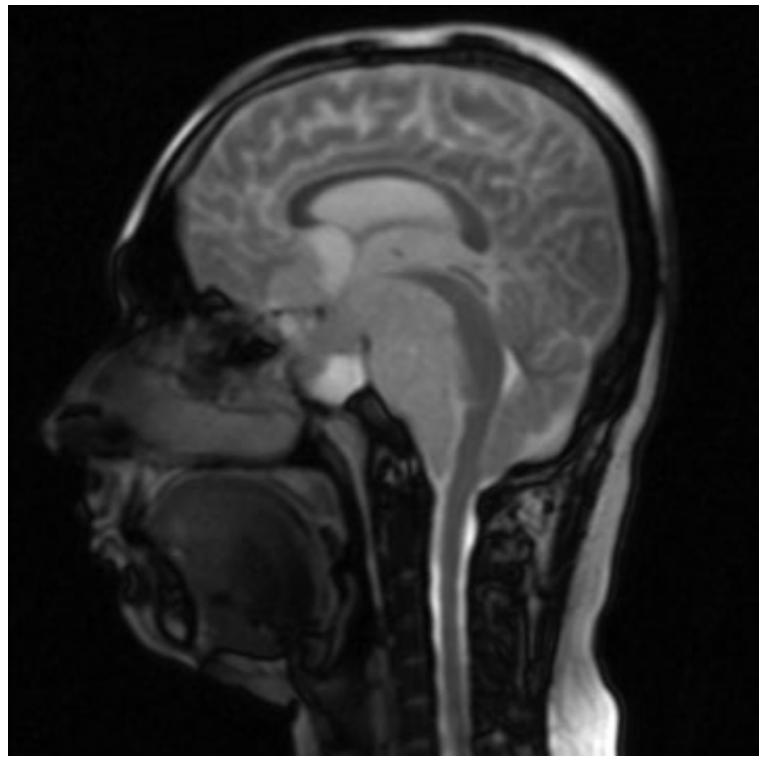

Fig. 1 Sellar lesion eroding the left sphenoidal sinus and extending up to the medial temporal gyrus and pons.

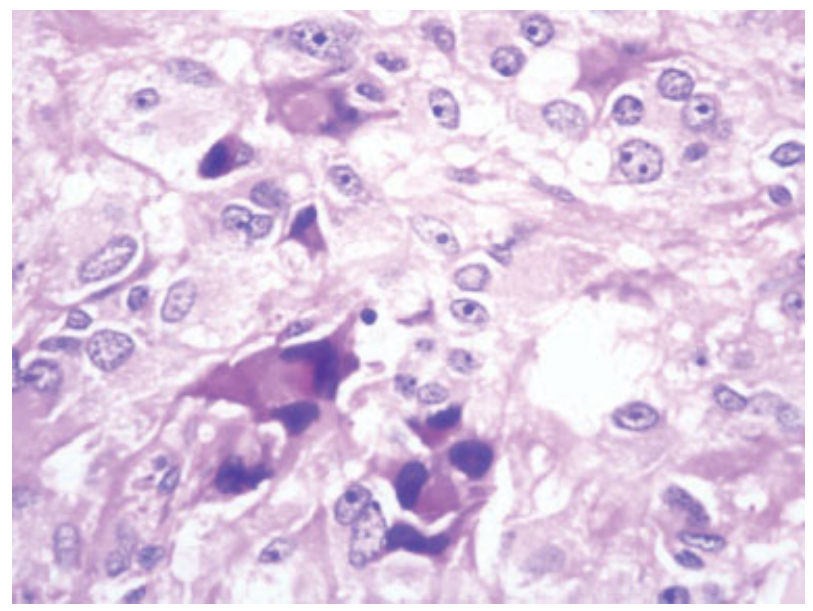

Fig. 2 High-power view (40x) showing medium to large polygonal cells (adenoma component) admixed with multinucleated cells (ganglion cell component).

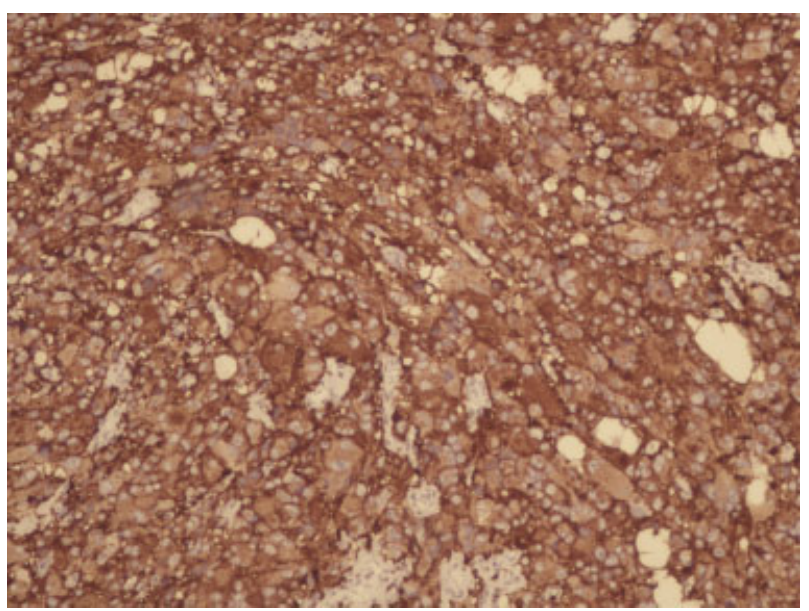

Fig. 3 Immunohistochemical markers for synaptophysin was positive in both components (10x).

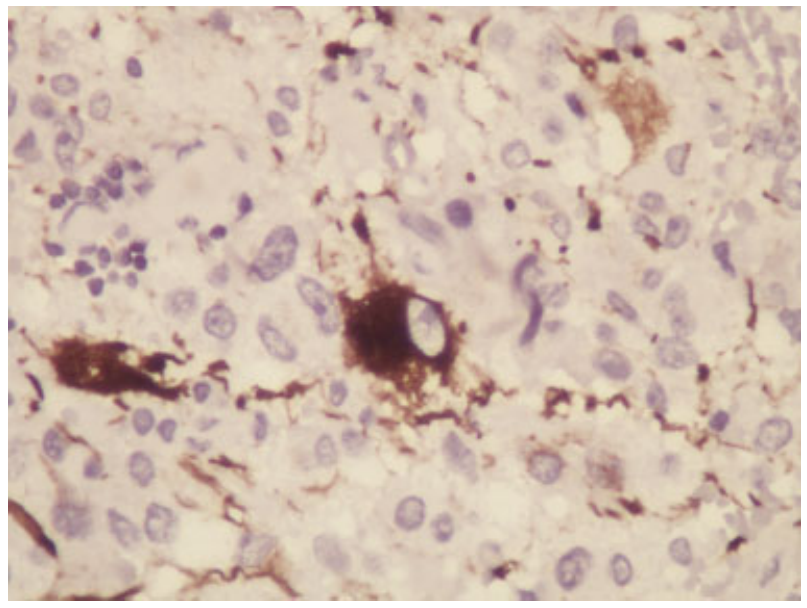

Fig. 4 Neurofilament protein was positive in cytoplasm of large ganglion cell (40x).

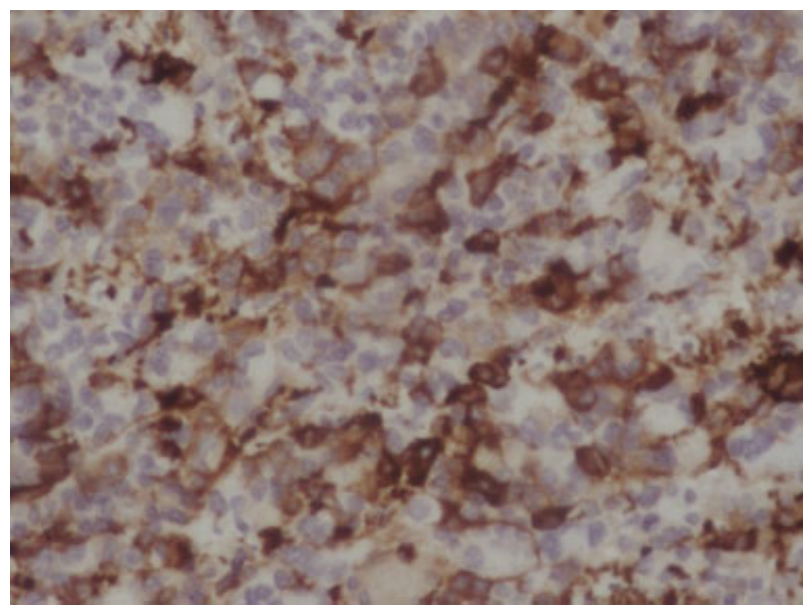

Fig. 5 Immunohistochemical markers for prolactin was positive in the adenoma component (10x).

\section{Discussion}

Ganglion cell containing pituitary adenomas are rare entities. They represent tumors originating in the sella turcica, which are composed of adenomatous and ganglion cell components. Different terminologies have been used to describe pituitary ganglion cell lesions, including pituitary adenoma with neuronal choristoma (PANCH), hypothalamic hamartomas, and hamartomatous gangliocytomas, which have led to nosologic confusion. ${ }^{1}$

A review of previous studies reveals that most of the cases of these tumors have been reported in women. ${ }^{2}$ This patient was an adult male. Most cases were macroadenomas $(>1 \mathrm{~cm}$ ). However, to the best of our knowledge, this is the first case of a ganglion cell containing pituitary adenoma with neuronal differentiation presenting as a giant adenoma $(>4 \mathrm{~cm})^{3}$ The anterior growth was also unusual for an adenoma that usually grows superiorly, inferiorly, or posteriorly. The cases reported in literature were diagnosed as GH secreting, while in a few cases, the tumor 
presented with symptoms of Cushing's disease and hyperprolactinemia. Although this patient's endocrinologic status was unavailable, the lack of clinical symptoms and negativity for hormones on IHC (except prolactin) favor a nonfunctioning pituitary adenoma which is exceptional. ${ }^{1}$ These tumors have demonstrated a benign clinical course.

Histopathologic study and IHC markers are essential to the diagnosis of this entity. The infrequent recognition of ganglion cells may, in part, be due to (1) infrequent IHC evaluation for its presence; (2) prominent nucleoli, particularly GH-secreting adenomas, obscuring its presence; (3) widespread synaptophysin immunoreactivity that may obscure the presence of coexisting small neurons; and (4) the presence of intermediately differentiated neuronal forms (as seen in ganglion cell tumors) that are difficult to recognize. Hence, pathologists need to be aware of this entity to arrive at the correct diagnosis.

The origin of these tumors is controversial, and the three main hypotheses have been proposed. The first hypothesis states that such tumors arise from the adenohypophyseal parenchyma into which hypothalamic neurons have abnormally migrated during the early phase of embryogenesis. The second hypothesis states that the pituitary adenoma is caused by excessive stimulation of the hypothalamic hormones by the heterotopic intrasellar ganglion cells. The third and presently accepted hypothesis suggests that the neuronal and adenomatous components originated from the transitional cells between neurons and adenohypophyseal cells of the embryonic rests (uncommitted stem/progenitor cells. ${ }^{1}$ Based on the findings of this case and review of literature, we partly agree with the first and third hypotheses, that this type of tumor may relate to embryonic cells. This lesion may develop from the abnormal migration of gangliocytic cells in the embryonic brain due to internal or external disturbance. Then, the ectopic ganglion cells keep the immature features in the abnormal location and lead to the tumorigenesis of the pituitary adenoma. If cells can be isolated and cultured from the specimen of this type of tumor, it would endow us with the ability to understand this entity better. ${ }^{4}$

\section{Funding \\ None.}

Conflict of interest

None.

\section{References}

1 Matyja E, Maksymowicz M, Grajkowska W, et al. Ganglion cell tumours in the sellaturcica in close morphological connection with pituitary adenomas. Folia Neuropathol 2015;53(03): 203-218

2 Qiao N, Ye Z, Wang Y, et al. Gangliocytomas in the sellar region. ClinNeurolNeurosurg 2014;126:156-161

3 Madsen H, Borges TM, Knox AJ, et al. Giant pituitary adenomas: pathologic-radiographic correlations and lack of role for p53 and MIB-1 labeling. Am J SurgPathol 2011;35(08):1204-1213

4 Zhou P, Ma L, Cheng S, Yin S, Jiang S. Combined gangliocytoma and non-functioning pituitary adenoma of the pituitary gland. Neurol India 2012;60(03):311-313 